\title{
Paideia dos Degredados: Raízes dos \\ CONDICIONAMENTOS INIBIDORES DA UnIVERSALIZAÇÃO \\ do Direito À EDUCAÇÃo no Brasil *
}

\author{
Gerardo Clésio Maia Arruda** \\ Flávio José Moreira Gonçalves***
}

Introdução. $1 \mathrm{O}$ sentido da colonização e alguns caracteres do colonizador português. 2 Relações de produção e formação da força de trabalho. 3. Poder e educação. Conclusão. Referências.

\section{RESUMO}

Neste artigo, faz-se um esforço para identificar as causas originárias das interposições que se construíram historicamente e que ainda obstaculizam a universalização do direito à educação na sociedade brasileira. Para tanto, as análises remetem ao período colonial e imperial com o intento de se apreender o sentido da colonização, os meandros da dominação e a estrutura hierárquica aí construídos e, posteriormente, consolidados. Portanto, averiguam-se as consequências desses processos para o delineamento da dinâmica das relações sociais e de poder. Assim, faz-se uma incursão nas relações econômicas buscando trazer à tona os elementos concretos que definem os interesses das classes dominantes, compreendidos como fundantes da organização política, portanto, que se encontram na base da regulação das relações sociais. Examinam-se ainda as relações de produção com o objetivo de verificar a necessidade de formação da força de trabalho, percebida como essencial ao entendimento da trajetória da normatização e das políticas públicas direcionadas ao campo da educação. Conclui-se, referenciando-se nessas questões, que a Constituição de 1824 dá início a uma normatização do direito à educação que inaugura um hiato abissal entre o que se propõe

* Revisão de Português do presente artigo realizada por Francisco Gomes Martins.

** Doutor e mestre em Sociologia, especialista em Geografia e graduado em Economia. Professor da Universidade de Fortaleza (Unifor) e do Centro Universitários Christus (Unichristus). Pesquisador da Fundação Cearense de Apoio ao Desenvolvimento Científico e Tecnológico (Funcap). E-mail: clesioarruda@yahoo.com.br

*** Doutor em Educação, mestre em Filosofia, mestre e graduado em Direito. Professor da Universidade Federal do Ceará (UFC), do Centro Universitário Christus (Unichristus) e da Universidade de Fortaleza (Unifor). Assessor Pedagógico da Escola Superior da Magistratura do Estado do Ceará (Esmec) e Pesquisador do Grupo de Pesquisa Hans Jonas, cadastrado no Conselho Nacional de Desenvolvimento Científico e Tecnológico (CNPq). E-mail: professorflavio@ymail.com 
como garantia constitucional e a realidade sociopolítica a qual está dirige.

Palavras-chave: Direito à Educação. Universalização. Constituição de 1824. Políticas Públicas.

\section{INTRODUÇÃO}

No transcurso da primeira metade do século XX, consolidou-se nos países subdesenvolvidos a percepção de que a ciência e a tecnologia seriam os instrumentos capazes de operar transformações nas normas orientadoras dos pensamentos e ações coletivas. Legitimou-se a crença segundo a qual, somente pelo intermédio do conhecimento, seria possível a superação do atraso econômico e do fosso abissal que extrema, social e culturalmente, seus segmentos populacionais.

É razoável afirmar que a partir do entendimento de que é inerente à ciência a formação de uma força transformadora, gerou-se na sociedade brasileira um consenso que enxerga neste fator um mecanismo instituidor de padrões reguladores de comportamentos coletivos propiciadores de melhorias nas dinâmicas de funcionamento das subestruturas econômicas, sociais e políticas. Numa palavra, plasmou-se por todo o tecido social a ideia de que por meio da ciência seria possível viabilizar a maximização dos recursos e geração de uma produção abundante, capaz de promover dignidade, dar condições de sobrevivência para todos e retirar da miséria, e da pobreza, segmentos populacionais que nelas se encontram imersos; bem como inaugurar um modus operandi na política que assegure os princípios democráticos. Como diz Florestan Fernandes: "todos anseiam por anular a distância histórico-cultural que os separa dos países adiantados, e por realizar, de modo equânime e completo, os ideais da vida humana consagrados pela moderna civilização ocidental" ${ }^{\prime}$.

Com efeito, a comparação de dados dos censos demográficos brasileiros de 1940 e 2010 indica a existência de mudanças significativas na distribuição da população por áreas geográficas e por setores econômicos. A população total, que em 1940 era de 41,2 milhões de habitantes, foi aumentada para 190,7 milhões; já a população urbana, que era constituída de 12,9 milhões de pessoas, saltou para um total de 160,9 milhões. O comportamento destas variáveis provocou uma mudança do índice de urbanização de $31,23 \%$, em 1940, para $84,36 \%$, em 2010. No concernente à distribuição dos trabalhadores nos setores de atividades econômicas, detectou-se em 1940 o percentual de 4,8\% de pessoas ocupadas na indústria de transformação e, em 2010, essa taxa era de 11,8\%. Assistiu-se, neste período, à transformação da sociedade brasileira de rural e agropecuária para urbana e industrial e de serviços. Entretanto, no Censo Demográfico de 2000, observava-se que o país possuía, entre as pessoas com 10 anos ou mais de idade, o equivalente a $4,4 \%$ com nível superior completo; somente nas duas últimas décadas é que se verificou a adoção de políticas públicas mais consistentes que elevaram esse índice, em 2010, para 7,9\%, o que representou um crescimento ${ }^{2}$ 
de $109,83 \%$. Apesar disto, ainda é baixo o percentual da população brasileira com nível superior, mesmo quando comparado com países da América do Sul.

O Brasil modernizou-se economicamente, tornou-se urbano e industrializado. Mas esta transformação seguiu uma trajetória que comportou 22 anos de um regime totalitário, e com base num sistema de livre mercado, produtor de mercadoria intensivo de mão de obra, com baixo nível de inovação tecnológica que não demandava qualificação elevada nem mesmo em larga escala. A sociedade brasileira é particularmente complexa, pois apresenta, em 2013, o 7º maior Produto Interno Bruto mas que ocupa a 84a posição no ranking mundial do Índice de Desenvolvimento Humano ${ }^{3}$; e comporta setores econômicos oligopolizados atuantes no mercado global intensivo em capital e um elevado contingente de trabalhadores inseridos em atividades informais, destituídos de proteção jurídica e com salário e jornada incerta, que engendrou uma Constituição reconhecida pela exaltação aos princípios da dignidade humana (art. $1^{\circ}$, III), da liberdade e da igualdade, mas que possui uma parcela de sua população que se coloca radicalmente contrária à efetivação de políticas compensatórias e de distribuição de renda.

É inegável a presença da mentalidade industrial no corpo político brasileiro, o que pode ser observado nos padrões reproduzidos nas diversas subestruturas, como em alguns setores do sistema educacional, por exemplo; por outro lado, subsistem normas concernentes ao patrimonialismo característico da sociedade rural, como se vê nos partidos políticos, em muitos dos quais ainda prepondera o personalismo com traços de neocoronelismo. Desta forma, pressupõe-se aqui que apesar da modernização econômica ocorrida após 1930, ainda não se superaram padrões característicos de uma sociedade agroexportadora erguida num modelo de exploração da terra assentada na monocultura e no trabalho escravo. Nestes mais de 80 anos de esforços permanentes de progresso econômico, via modernização da produção de bens e serviços, ainda não se implantou plenamente uma mentalidade industrial apesar de já se imiscuírem em nosso cotidiano padrões da sociedade informatizada.

Encontram-se aí as barreiras que dificultam a universalização do acesso à educação em todos os níveis, equânime em sua capacidade de dotar todos os indivíduos de iguais condições de disputa. Por isto, é preciso trazer para a compreensão da dinâmica da estrutura econômica elementos culturais, portanto, também políticos, no intuito de identificar os obstáculos interpostos à consolidação dos marcos regulatórios da sociedade capitalista industrial democrática, que se assenta na igualdade de oportunidades e de competitividade a partir de uma educação extensiva a todos na mesma medida e qualidade. Como destacam Burbules e Torres, estas exigências de universalização ampliam-se consideravelmente na contemporaneidade: "dessa forma, as implicações políticas da educação superam as condições de um indivíduo a ser educado e constituem um conjunto estratégico de decisões que afetam a sociedade maior, de onde vem a importância da educação como política pública e o papel do Estado 4 . 
Assim, buscar-se-á neste artigo trazer luzes para a compreensão dos fatores determinantes do sistema educacional brasileiro a partir de uma análise que contempla a dinâmica da estrutura econômica e a constituição das estruturas de poder, enfatizando a etapa em que é hegemônica a produção agroexportadora do período colonial.

\section{O SENTIDO DA COLONIZAC̣ÃO E ALGUNS CARACTERES DO CO- LONIZADOR PORTUGUES}

O delineamento de alguns traços marcantes e definidores do processo de colonização auxilia no entendimento da lógica das ações no exercício da exploração da terra e na dominação da força de trabalho, o que também possibilita a compreensão dos meandros da produção e das relações de produção originários do Brasil colonial, bem como da formação e da adequação da força de trabalho para o funcionamento das estruturas produtivas.

Para alcançar este intento, fez-se aqui a opção de se trilhar o caminho percorrido por Bosi ${ }^{5}$ que toma como ponto de partida, em sua reflexão, o entendimento conotativo das palavras cultura, culto e colonização. Esclarece inicialmente, este autor, que as expressões "eu moro", "eu ocupo a terra", e, por decorrência, "eu trabalho", "eu cultivo o campo" são derivadas do termo latim colo. Encontra-se aí a origem da palavra que exprime aquele que tem o direito por herança à terra, o incola, o seu habitante natural, e o que ocupa a terra que não lhe pertence, o inquilinus. Em colo se encontra a denotação de algo que é transitivo, percebido na ação de um agente em relação a uma coisa, a pessoa que ali está morando e cultivando a terra. É desta perspectiva que Bosi ${ }^{6}$ explica o significado de colonia, que deriva da raiz colo, "espaço que se está ocupando, terra ou povo que se pode trabalhar e sujeitar.”

Assim compreendido, colo se distingue do termo colonus, referindo-se àquele que cultiva a terra para um outro; portanto, não é o dono, mas sim alguém a quem se concedeu o direito de explorar a terra. Trata-se de um administrador de bens alheios. Este entendimento, segundo $\mathrm{Bosi}^{7}$, é que vai gerar a classificação da colonização dividida entre o tipo que objetiva o povoamento e o tipo que tenciona a exploração da terra. Esclarece o autor que colo abrange os dois tipos, pois este termo encerra os sentidos de "eu moro" e "eu cultivo". Daí, então, Bosi ${ }^{8}$ nos coloca diante do seguinte dilema: o que precisamente diferencia os termos habitar e o cultivar do colonizar?

O incola, como já explicitado, é aquele que nasce em um espaço e que tem direito a ele por herança, ao se deslocar para outro espaço, passa à situação de colonus, uma vez que nesta condição está explorando uma terra que é de outro e não sua por direito natural. Porém, a colonização é bem mais do que uma migração em busca de trabalho, o ato de colonizar está para além da geração de riqueza na terra de outro, trata-se de transladar um modo de vida. É, em última instância, uma ação que tem como objetivo operar, impor e consolidar 
uma forma de produzir e, por conseguinte, instituir as relações sociais que a ela se encontram associadas. A partir destas relações sociais impostas, criam-se os mecanismos capazes de tornar costumes, hábitos e as morais aí instituídas como os novos parâmetros ordenadores das interações sociais travadas no espaço colonizado. Este processo não se resume a uma mera transposição do modo de vida original, pois o seu desenvolvimento arregimenta forças coercitivas que o tornam irresistível em suas ações transformadoras. Nas palavras de Bosi: "há um plus estrutural de domínio, há um acréscimo de forças que se investem no desígnio do conquistador emprestando-lhe às vezes um tônus épico de risco e aventura." ${ }^{9}$

É no cerne deste processo de imposição de um modo de vida, de um modo de produção e das relações sociais inerentes, que se forja o tipo de dominação praticada, pois o ato de ocupar a terra para explorar pressupõe o mandar fazer, que implica desabilitar as técnicas de produção existentes e sobrepor uma maneira de fazer diferente; então, é preciso inculcar formas de agir e pensar concernentes à produção objetivada. O poder exacerbado característico da colonização e do colonizador quinhentista foi forjado nas estruturas elementares do feudalismo; remonta mesmo ao seu início, pois regulava as relações entre romanos e bárbaros. Como explica Miceli ${ }^{10}$, "bárbaros também possuíam suas leis, mas não podemos tentar compreender aquela sociedade sem entendermos que suas relações estavam baseadas no poder sobre os homens e sobre a terra ao mesmo tempo."

A dominação é particular a toda colonização, está contida nas colonizações de todos os tempos, portanto, possui um caráter de universalidade concernente ao processo civilizatório. A ação de colonizar aparece nas sociedades, seja como forma de resolução de tensões internas, seja objetivando equacionar problemas demográficos ou econômicos. Com relação às motivações para Portugal colonizar, foi central a necessidade de expansão do comércio como alternativa de ascensão da burguesia. Vê-se, assim, que em Portugal, como em outras formações sociais de outros tempos, a iniciativa de colonizar é sempre ocasionada por uma busca "de resolução de carências e conflitos da matriz e uma tentativa de retomar, sob novas condições, o domínio sobre a natureza e o semelhante."11

Por outro lado, a dominação aparece como sustentáculo para a colonização porque é o que garante a perpetuação dos colonizadores à frente da exploração da terra e dos íncolas. A ação colonizadora é uma ação de conquista, mas que traz em si o desejo da manutenção do que foi conquistado. Assim sendo, é um processo que não se finda na geração dos conquistadores. A colonização busca perpetuar-se por meio da transferência de suas ideias às gerações seguintes; para tanto, formam-se os herdeiros da colonização no domínio das técnicas de dominação e subjugam-se os íncolas por intermédio de um processo de inculcação de regulações próprias do modo de vida trasladado e reelaborado. Ou seja, da transmissão de valores culturais, entendido como um complexo constituído por um "conjunto das práticas, das técnicas, dos símbolos, e dos valores que se devem transmitir às novas gerações para garantir a reprodução de um estado e coexistência social. A educação é o momento institucional marcado do processo.” ${ }^{12}$ 
Vê-se que os colonizadores compartilham motivações, dado que têm em comum a procura fora de seu território de alternativas de soluções para os problemas engendrados na dinâmica de suas formações sociais, além do que estendem alhures o exercício da dominação sobre a natureza e as pessoas. Mas é interessante aos propósitos aqui delineados que se faça um esforço para explicitar a mentalidade dos colonizadores da Terra do Pau-brasil. Para tanto, vale iniciar com o pensamento de Sérgio Buarque de Holanda ${ }^{13}$ que, ao referenciar a propensão para a fantasia e o mistério presentes nos relatos dos viajantes europeus na era dos grandes descobrimentos, esclarece que a literatura portuguesa quinhentista não acompanhava esta tendência e se apresentava de maneira mais realista, o que denotava um certo desassombro diante do exotismo do Novo Mundo.

Contudo, deve-se apreender o realismo dos escritos lusitanos não como uma forma que expressava um espírito moderno, uma vez que tal comportamento se estribava no cerceamento decorrente da limitação humana e territorial. Holanda ${ }^{14}$ ainda levanta a hipótese de que os relatos meticulosos, que apreendiam o real, que não transcendiam o sensitivo, não corresponderiam a uma mentalidade que rompia com o tradicionalismo medieval; embora pudessem levar ao entendimento de que se tratava de uma superação do arcaísmo, na verdade, o realismo português denotava um atraso em relação ao pensamento dos humanistas e aos ideais do Renascimento.

Lembra Holanda ${ }^{15}$, que na primavera da Idade Moderna assistiu-se a um recrudescimento de algumas estruturas determinantes da Idade Média, de tal maneira que se tornou a valorizar os conhecimentos produzidos pela alquimia e a astrologia, e até mesmo a magia floresceu e voltou a influir de forma vigorosa na visão de mundo da época. Também no pensamento, emergiu uma defesa tenaz do aristotelismo e da retórica, que eram entendidos como mais capazes de expressar o real e como instrumento eficiente de persuasão; mais precisamente, entre os ibéricos forjaram-se ardorosos defensores da escolástica, assim como, ocuparam significativo espaço pensadores que faziam resistência à lógica e à dialética, que se opunham às elaborações de cunho abstrato e especulativo.

É preciso pontuar que esta resistência do arcaísmo, que ressurge como barreira impeditiva às estruturas fundantes da modernidade, é mais salientada entre os ibéricos; e como chama a atenção Holanda ${ }^{16}$, entre os portugueses, a escolástica e a retórica tomam corpo dentro e fora da academia. Para uma compreensão do quão contraditório se mostra o fazer simultaneamente a defesa do pensamento escolástico e ser protagonista das grandes descobertas, vale lembrar que os escolásticos fizeram um esforço de localizar na filosofia grega fundamentação para a doutrina cristã, de sorte que legitimavam os conceitos embasados na razão desde que não obnubilassem a verdade das escrituras. Isto aparece na explicação de Senna sobre o pensamento econômico da Idade Média:

De maneira geral, os motivos econômicos eram tratados como suspeitos. Em particular, o comércio tinha a sua importância, mas era visto como algo perigoso para a alma. Na comparação com o 
artesão, o comerciante estava sempre em desvantagem. Enquanto o primeiro trabalhava para o seu sustento, entendia-se que o segundo perseguia o turpe lucrum. O comerciante, aquele que compra com o objetivo de vender mais caro, enxerga apenas o lado pecuniário, estando totalmente desprovido de qualquer senso de espírito público, ou de caridade ${ }^{17}$.

Entre os séculos XV e XVIII, um período aproximado de 300 anos, constituíram-se os pontos dogmáticos que se denominaram, na política econômica, de mercantilismo. Em sua base está a emergência do Estado-nação na Europa, que passou a demandar recursos em volumes bem mais significativos do que os necessários à organização social assentada nos feudos. Isto deu robustez ao setor financeiro, substanciado na ideia de fomento do comércio, fonte de arrecadação de recursos do Estado por via da tributação; além do que, o papel do financiamento foi incrementado tanto pela necessidade do permanente crescimento da atividade comercial, como pela insuficiência dos recursos arrecadados pelo Estado para fazer face às suas despesas, considerando a ineficiência dos sistemas de arrecadação existentes e o descontrole dos gastos estatais, em razão dos ainda primários meios de controle e a frágil produção de conhecimentos acerca da importância dos marcos regulatórios das ações do setor público ${ }^{18}$. Com isto, a ideia do lucro foi-se sobrepondo à da usura, de tal maneira que a busca de ganhos e da acumulação de riqueza com a atividade comercial e financeira aderiu aos espíritos da época e criou as condições para a inauguração das instituições caracteristicamente modernas.

Nos anos 1500, deu-se a passagem da desorganização da Idade Média para o surgimento de uma nova ordem, assentada na lógica comercial. Como destaca Manacorda,

De fato, é agora que começa a se propor novamente o problema do como e quanto instruir, quem é destinado não tanto ao domínio, mas à produção. Na verdade, a instrução ainda não era difundida universalmente, embora os dados fornecidos por Villani, referentes à Florença do século XIV, nos façam pensar nalgumas ilhas excepcionais. Na realidade, poder-se-ia repetir com Juvenal: rara in tenui facundia panno (a instrução não é frequente em quem veste pobres panos). E Alciato, espírito nobre e erudito, repetirá com elegância no seu libro sobre os Emblemi (na edição de Lion, de 1551) sob o título: Paupertatem summis ingeniis obesse, ne provehantur (a pobreza impede aos máximos talentos progredir) [...] nessa época já se começa a falar de uma instrução útil, e não somente de uma aculturação imposta, também para as classes subalternas e para os produtores. ${ }^{19}$

A condenação da busca do lucro cede espaço para uma racionalização em que o ganho é buscado de forma permanente e não como algo que acontece ao acaso. Inaugura-se entre os homens de negócios uma forma de agir em que o cálculo do uso dos meios adequados para se alcançar um fim visado é o pressuposto básico. Os portugueses se situaram nos dois polos desta tensão, 
uma vez que produziam uma literatura e um pensamento contrários à lógica e à racionalidade balizadora da produtividade moderna ao mesmo tempo em que se lançavam na aventura de construir as rotas marítimas que, em última instância, deram sustentação às ideias mercantilistas.

Entre os colonizadores portugueses, esta condição em que as ideias não correspondem às ações vão-se reproduzindo noutros contextos, como o essencial que vai se perpetuando nas mudanças que se dão num processo contínuo e permanente. Isto também pode se depreender do encontro da cultura europeia com os gentios e a terra brasileira. Daí, pode-se deduzir o seguinte fato: ao desencanto quase imediato que acomete os donos do novo mundo com o achado que os levou ao êxtase, logo que se perceberam diante de algo que demandaria enorme esforço para torná-lo em empreendimento gerador de ganhos, sobreveio a invenção de uma racionalidade ímpar que mobilizou trabalho e terra, recursos já existentes, e permitiu a extração de dividendos com um mínimo de contrapartida. Uma combinação de meios que, primeiro, adotou a força de trabalho dos gentios, quando da riqueza obtida exclusivamente com a coleta dos recursos naturais; posteriormente, quando vislumbraram a participação no comércio mundial de maneira mais alargada, articularam um sistema de produção que envolvia a participação de três continentes: em Portugal, procedia-se o gerenciamento do empreendimento; na África, o aprisionamento da força de trabalho, explorada no regime de escravidão; e, no Brasil, a produção de uma mercadoria - o açúcar - fortemente demandada pelos grandes centros consumidores.

Uma nação pobre diante de uma riqueza natural abundante, um Estado de extensão territorial diminuta em face de um continente a ser explorado, estas foram as condições que se impuseram aos colonizadores da Terra do Pau-brasil. Os portugueses reproduzem de maneira ampliada a característica contraditória do período iluminista; como se refere Roberto DaMatta, ${ }^{20}$ trata-se de uma época em que havia "motivações que objetivavam manter desigualdades, tanto quanto impulsos libertadores, nascidos dos ideais igualitários que, paradoxal e dialeticamente, surgem nesta mesma Europa aristocrática e hierarquizada”. Aos portugueses, católicos, inseridos na lógica do comércio mundial, produtores de literatura, estavam dada a possibilidade de atrair colonos, desde o primeiro momento, mas teriam que contar com a contribuição de outras nacionalidades, dada sua população exígua. Mas, talvez porque tenham avaliado que o risco de perder a posse das terras era muito elevado, optaram pela exploração do trabalho de uma etnia transladada de seu espaço e distribuída desordenadamente em outro, submetida a um controle despótico que os relegavam a uma expectativa de vida de aproximadamente dez anos.

Esta organização deixava os dominadores confortáveis quanto a ameaças internas, pois revoltas eram possíveis e aconteciam, mas sem capacidade para articular uma alternativa de poder. $\mathrm{O}$ domínio assim exercido garantiu que um pequeno número de pessoas controlasse muitos, uma vez que aliada a força física somava-se a imposição de condições de sobrevivência precária e, sobremodo, 
operava-se nas relações sociais uma tentativa permanente de negação da cultura dos povos subjugados. As manifestações culturais dos nativos e dos africanos eram fortemente cerceadas; atos religiosos, por exemplo, eram taxados de rituais demoníacos; enquanto os encontros para entoar cânticos e praticar jogos de roda e danças eram denominados de arruaças. Enfim, ajuntamento de pessoas e reuniões das classes subalternas, fosse para o exercício de atividades de lazer ou religiosas, foram sempre vistas como ameaça à ordem e aos bons costumes. Uma prática que se manteve muitos anos depois do início da colonização da terrae brasilis, embora a Constituição do Império (1824) tenha assim expressado em seu art. 5', dando "liberdade" de reunião religiosa: "A Religião Catholica Apostolica Romana continuará a ser a Religião do Imperio. Todas as outras Religiões serão permitidas com seu culto domestico, ou particular em casas para isso destinadas, sem fórma alguma exterior de Templo"21.

Schwartz ${ }^{22}$ procura deslindar a lógica do comportamento do colonizador do Brasil com base na dissociação entre as ideias correntes e a forma como se dava a organização dos interesses coletivos. Assim, aponta a inserção nacional no comércio mundial como exemplar no exercício de uma prática que se mostra irreconciliável às ideias que lhe dão sustentação, pois a coleta de recursos naturais e a produção de mercadorias no Brasil se concretizaram como ações que se respaldam, portanto, que têm as forças originárias que lhes dão partida e as objetivam, numa estrutura de pensamento cujos princípios são a liberdade para contratar, o trabalho livre, o direito de ir e vir assegurado, elementos essenciais ao livre cambismo; entretanto, a riqueza que se produzia no país e entrava na circulação mundial de mercadorias se assentava no trabalho escravo.

No despertar da modernidade engendrou-se um sistema econômico em que o comércio ascendeu à condição de atividade principal em detrimento do artesanato; a moeda incorporou a função primeira de mediação de troca a de especulação objetivando o lucro, assim desmoronando as barreiras impostas pela ideia da usura, assentada na Teoria do Justo Preço, defendida pela Igreja; o Estado assumiu o papel de regulador das forças necessárias para a realização do lucro e da acumulação de capital. Aos pressupostos desta política econômica, articulavam-se pensamentos que confrontaram crenças arraigadas do ancien regime, como "a autonomia da pessoa, a universalidade da lei, a cultura desinteressada, a remuneração objetiva, a ética do trabalho etc." ${ }^{23}$. Interessa-nos ver, agora, como se deu, no Brasil, a transposição deste modo de vida pelo colonizador português, ou seja, como surgimos para a economia mundial, quais as características da produção e as técnicas aqui desenvolvidas, que pensamentos deram sustentação à política econômica nacional, e daí buscar compreender o papel da educação na formação cultural edificada nas relações sociais de produção.

\section{RELAÇÕES DE PRODUÇÃO E FORMAÇÃO DA FORÇA DE TRABALHO}

Referir-se a produção de mercadoria no Brasil é a priori afastar a hipótese já levantada de que se reproduziram no período colonial instituições próprias 
do feudalismo. Ora, tanto o que fora objeto de coleta como o que aqui se produziu é resultado da expansão comercial e estava destinada a entrar na esfera mundial de intercâmbio. Portanto, o Brasil deste período é parte da dinâmica do capitalismo comercial e, na verdade, trata-se de um espaço que aparece por decorrência de um empreendimento racional, com todos os condicionantes da racionalidade burocrática moderna, pois como diz Furtado ${ }^{24}$ "durante três quartos de século os portugueses investiram em conhecimentos teóricos e práticos para se capacitarem a explorar terras longínquas com base em meios econômicos escassos."

No que concerne ao funcionamento desta estrutura produtiva é preciso salientar que o controle é realizado de fora para dentro, onde a regulação é pensada na Metrópole e a supervisão ocorre para atender interesses aí originados. Este funcionamento acarretou implicações culturais e políticas, uma vez que, de um lado, o grupo que detinha o controle da produção não foi apartado dos conhecimentos produzidos na Europa, o que recrudescia a capacidade de controle a partir da apropriação e adoção de novas técnicas, situação contrária a das outras etnias que foram apartadas de seu modo de produção, de suas instituições, até mesmo de seus idiomas. Por outro lado, o gerenciamento do sistema realizado em Portugal inibiu a emergência de uma burguesia local, cônscia de seus interesses e com capacidade de influir no seu destino, não floresceu uma classe comercial com protagonismo político. Assim se refere Furtado acerca da imbricação do sistema econômico de produção e o cultural sob a égide da Metrópole portuguesa:

A persistência dos traços dominantes da matriz cultural original explica-se pela estabilidade do sistema de dominação social latifundiário-burocrático. $\mathrm{Na}$ ausência de uma classe mercantil poderosa tudo dependia da Coroa e da Igreja. O processo de criação cultural é balizado por essas duas instituições ${ }^{25}$.

A influência da Coroa e da Igreja na determinação da forma e conteúdo do sistema econômico e da ordem cultural construíram uma sociedade assentada na dicotomia elite-povo. Como destaca Saviani ${ }^{26}$, "há uma estreita simbiose entre educação e catequese no Brasil. Em verdade, a emergência da educação como fenômeno de aculturação tinha na catequese a sua ideia-força". Os meandros do funcionamento do sistema econômico colonial brasileiro nos permitem visualizar os fundamentos que contribuíram para a edificação de uma cultura que secundariza as classes populares ao ponto de negar-lhes ao máximo as benesses do excedente produtivo, legando-as a um consumo marginal.

Dowbor $^{27}$, ao descrever a formação do capitalismo dependente no Brasil, salienta o momento que vai da descoberta até a proclamação da independência (1500 a 1822) e o que se estende do final deste período até os anos 1930; sendo que o primeiro corresponde à fase portuguesa de dependência colonial, enquanto o segundo se caracteriza como a fase inglesa de dependência neocolonial. $\mathrm{O}$ autor é taxativo na defesa de que nos três séculos do período colonial foram lançadas 
as bases do Brasil contemporâneo. E no intento de compreender a constituição de seu capitalismo dependente parte do pressuposto de que à medida que as conquistas ultramarinas sucediam-se, simultaneamente, reconfiguravam-se a divisão internacional do trabalho e as relações mundiais de produção. Portanto, a determinação do que e como se produzia no Brasil era imposta de fora para dentro, ou seja, a necessidade da produção de mercadorias na Europa definia a dinâmica da produção colonial.

Em outras palavras, a economia na periferia se organizava em função do capitalismo europeu. Todavia, é preciso considerar que primeiro a produção do centro se realizava com base nos insumos e matérias primas locais e só quando necessário recorria-se a outros espaços de fornecimento. Tem-se, então, que a procura no centro é que determina a produção capitalista na periferia, de tal maneira que a dinâmica secundária do centro é o que fomenta exclusivamente a dinâmica principal da periferia. Nas relações de produção assim constituídas é que se consolidarão as classes dominantes e, por conseguinte, sua função na produção mundial.

É indiscutivel que esta ligação prematura com o capitalismo europeu reforçou as classes dirigentes locais e cristalizou relações de produção existentes, ao mesmo tempo que mudava sua orientação. Vendo no monopólio do contato entre o capitalismo europeu e as estruturas locais de produção o melhor meio de fortalecer-se, as classes dominantes locais tornaram-se intermediárias deste intercâmbio. Participavam do excedente produzido sob diversas formas, mas submetiam-se de maneira crescente à dinâmica do capitalismo do centro ${ }^{28}$.

Nas circunstâncias até aqui descritas, onde a economia na periferia se constituiu, para além de dependente, submissa às necessidades da economia europeia, tem-se que, na origem, se estruturou uma divisão do trabalho onde a acumulação de capital se realizou mais fortemente no centro, enquanto a produção colonial deu partida a uma especialização de sua produção marcadamente subsidiária; assim, detendo uma acumulação de capital sempre inferior, efetivada com base na produção de mercadorias demandantes de extensas faixas geográficas e de baixa remuneração. Tomando-se como referência o Brasil Colônia, vê-se que o jogo de forças instituidoras da divisão internacional do trabalho o transformou numa grande plantation especializada principalmente na cana-de-açúcar, algodão e café.

É na submissão da economia local à produção de fora que se elaboram as condições para a organização de uma economia pré-capitalista. Isto porque a acumulação aqui realizada estava atrelada a uma dinâmica externa, de sorte que escapava à lógica da busca permanente pela produtividade, via aperfeiçoamento dos processos produtivos. Uma vez que o motor impulsionador do desenvolvimento tecnológico não se dava a partir da dinâmica interna, da busca pela inovação motivada pela conquista de novos mercados, a qualidade e variedade da produção eram determinadas pela produção do centro, o que levou a obrigatoriedade 
de aqui se produzir matérias primas de baixo custo e com parcos investimentos de capital, ou seja, com elevada concentração de trabalho de baixo conteúdo tecnológico, baseado no dispêndio de energia muscular e não requerente de habilidades cognitivas.

É preciso acrescentar que na economia do centro a força de trabalho exerce uma função primordial na economia, ou seja, funciona como objeto de realização da produção, dado que além de produtor da mercadoria é também consumidor. Quando se reflete acerca da economia na periferia se detecta que a produção está destinada para fora, sendo que a força de trabalho local só marginalmente se coloca como contrapartida de consumo, seja do açúcar, do café ou do tabaco. Ademais, o consumo dos dominantes coloniais para atender suas necessidades não atendidas pela produção local, por exemplo, roupas, mobiliários etc., se realizava por intermédio da importação. O lucro da Colônia se transferia para a Metrópole por intermédio do consumo dos dominantes. Em suma, como defende Dowbor ${ }^{29}$, além da distância de acumulação de capital que favorecia exponencialmente um lado da relação internacional do trabalho, a relação de produção entre nações do centro e da periferia gerava as condições para as relações de produção pré-capitalista no Brasil, dado que na dinâmica da economia colonial a força de trabalho só participava da produção e não de sua realização, via consumo, assim, pode-se manter integrado à lógica do capitalismo mesmo com a prática do trabalho escravo, servil ou assalariado de muito baixa produtividade, qualidade e remuneração.

A colonização brasileira apresenta características que a especifica e a diferencia das demais colonizações. Na América espanhola predominou a exploração da mineração, o que direcionou a produção agrícola para o abastecimento interno; na América do Norte, verificou-se um rompimento com o capitalismo dependente resultante da Guerra da Independência e da Guerra da Secessão, quando a partir daí a produção passou a se orientar por interesses do mercado local. O Brasil, por sua vez, manteve-se preso a expansão do capital europeu mesmo após a independência, e estendeu o modo de produção pré-capitalista apoiado no trabalho escravo e dependente da demanda de produção da Europa e, posteriormente, dos Estados Unidos ${ }^{30}$. Esse modo de produção tem a sua forma acabada na empresa agroexportadora monopolista, que garantia a exclusividade no intercâmbio com o mercado externo, negando a possibilidade do aparecimento de outros fornecedores locais - familiares e empreendimentos de pequeno e médio porte; como também, garantia a manutenção do poder local, e através do uso da força não deixava margem para sobrevivência que não fosse via trabalho nas grandes plantações, seja no trabalho escravo ou no servil.

Na perspectiva portuguesa, como sugere Gilberto Freyre, na obra Casa Grande \& Senzala ${ }^{31}$, uma tese controversa e assaz combatida, a empresa agroexportadora surgiu como uma necessidade imposta pelas circunstâncias, pois as primeiras explorações em busca do ouro e da prata foram frustradas e as incursões dos franceses, principalmente, na costa brasileira demonstravam que era real o 
interesse de estrangeiros pela colônia, e devido a sua escassez populacional, que não permitia a transferência de famílias, restaram-lhes a alternativa da produção monocultural-escravocrata. Por outro lado, refletindo-se sobre a emergência da empresa agroexportadora centrado nas questões econômicas, é preciso considerar que se verificou a perda de importância, ao final do terceiro decênio dos Quinhentos, da atividade da extração de madeira, que era menos atrativa para a indústria têxtil do que as madeiras asiáticas comercializadas pelos italianos, que se prestavam à tinturaria mais eficientemente ${ }^{32}$. Assim, o desenvolvimento da atividade produtora do açúcar restou como alternativa possível para a ocupação e, por conseguinte, a manutenção da posse do Brasil. Alternativa que se tornou factível em função do aumento do preço desta mercadoria no mercado mundial. A produção exclusivamente destinada ao mercado externo gerava as condições para a submissão dos dirigentes da colônia aos aristocratas da Metrópole. O produto localmente concebido se realizava numa circulação que se concretizava no mercado europeu, somente alcançável através da intermediação dos comerciantes sediados em Portugal, o que garantia o atendimento da necessidade de expansão de sua burguesia.

A opção pela produção do açúcar direcionado para o mercado mundial marcou profundamente a constituição e consolidação da organização social que se seguiu no Brasil. A empreitada demandava substanciais recursos, para tanto deveria ser atrativo na perspectiva da geração de lucro. Com efeito, a Metrópole instituiu um sistema que já de partida concentrava a propriedade nas mãos de poucos:

A propriedade foi distribuída em regime de sesmarias, tendo-se conferido prioridade à concessão das terras situadas junto dos rios a quem dispusesse ou pudesse reunir capitais para instalar engenhos hidráulicos, ou seja, em primeira linha, aos nobres que muitas vezes se associavam a armadores ou mercadores "de grossos cabedais" como o exemplificam os casos de Martim Afonso de Souza ou de Pero de Góis ${ }^{33}$.

A lavoura da cana-de-açúcar só se mostrava rentável se realizada em largas extensões de terra, o que demandava muitos braços, portanto, investimento em mão de obra escrava. Assim, os senhores de engenho, que transformavam a matéria prima em produto acabado, monopolizavam a compra dos plantadores do entorno de suas propriedades. Tem-se aí que as lavouras estavam a cargo dos senhores de engenho e de plantadores, sendo que os primeiros se apropriavam de parte mais substancial da produtividade, pois ao transformar a matéria prima fornecida pelos que só plantavam retinham também uma parte da mais valia produzida por estes. E ambos estavam embasados num custo de força de trabalho equivalente aos limites mínimos da sobrevivência. Forma-se, então uma estrutura social dividida em três segmentos, onde aparece mais bem delimitada uma minoria de grandes proprietários e produtores de açúcar no topo da pirâmide, um grupo de lavradores proprietários ou arrendatários e um expressivo contingente de escravos. 
O complexo açucareiro era formado pela casa-grande, lugar da administração e atividades de direção, onde se controlavam as compras e vendas, o funcionamento das lavouras, moendas, oficinas, transportes e mão de obra; a senzala, onde se alojavam os escravos; e a capela, responsável pela cristianização dos escravos recém adquiridos e pela condução dos rituais religiosos. Este complexo comportava os trabalhadores livres que exerciam as seguintes funções especializadas: "mestre de açúcar, ajudante do mestre, purgador, caldeireiro, caixeiro, ferreiro, carpinteiro, agente escrivão e feitor" ${ }^{34}$. A existência destes trabalhadores livres, assalariados empregados nas fazendas, bem como os artesãos e outros trabalhadores por conta própria, que prestavam serviços nas fazendas, não corrompia a estrutura social que se assentava numa minoria de muitas posses, outra de parcos recursos e uma maioria de trabalhadores escravos imersos em condições de sobrevivência indignas.

As outras atividades surgidas no período que compreende a fase portuguesa da dependência colonial não alteraram a estrutura fundada na produção açucareira, de sorte que, até meados do século XIX, forjou-se no Brasil uma organização política e social, que se erigiu por sobre as relações sociais de produção que deram sustentação a economia do açúcar. Com efeito, todas as atividades econômicas gravitavam em torno desta produção, pois funcionavam como atividade de abastecimento ou como geradora de recursos complementares.

Numa síntese, a partir da análise de Prado Júnior ${ }^{35}$, e iniciando pela produção do tabaco, que em determinados períodos aproximou-se do açúcar em termos de lucratividade, tem-se que o seu desenvolvimento, ocorrido principalmente na Bahia e Sergipe, visava a comercialização na Europa; porém, parte significativa era utilizada no escambo para a aquisição de escravos africanos, assim como a aguardente, subproduto da indústria açucareira. Este historiador da economia brasileira distingue ainda na produção colonial a chamada economia de subsistência, completamente dependente e subsidiária aos produtos destinados à exportação.

A produção dos gêneros alimentícios foi por excelência parte substancial da economia de subsistência. O seu desenvolvimento se deu primeiramente com base na atividade desenvolvida nas proximidades das lavouras canavieiras, em lugares destinados a este fim, portanto, de produtividade inferior, pois as terras férteis destinavam-se a plantação da cana-de-açúcar. Os mesmos trabalhadores empregados na lavoura e engenho dos canaviais eram utilizados na produção de alimentos, nos dias de folga e feriados, de sorte que parte do custo de manutenção dos escravos era suprida por eles próprios. Os raros e pequenos núcleos urbanos eram abastecidos pelas sobras do que se plantavam nas lavouras canavieiras; porém, aos poucos, foi-se ampliando a demanda por alimentos, o que propiciou o surgimento de uma categoria de lavradores com características assemelhadas aos campesinos europeus.

Os índios foram os primeiros produtores de alimentos. Já praticavam uma agricultura nômade e de pequena monta, e se especializaram na plantação de mandioca, milho, arroz e feijão. Posteriormente, incorporados os hábitos 
europeus e predominado a mestiçagem, estes produtores constituíram-se numa classe intermediária entre os escravos e os grandes proprietários, mas inseridos num modo de vida limítrofe ao estado de sobrevivência precária.

Restrita aos pequenos latifúndios de baixa produtividade, esta economia nunca atendeu as necessidades alimentares da população local, que foram agravadas no século XVIII com a ampliação das populações urbanas. Para os grandes proprietários, a precariedade desta economia não era problema, pois o lucro elevado das exportações compensava o alto custo da alimentação. Eis aí o elemento fundante da apartação da sociedade brasileira em termos de condições materiais. Ou seja, na edificação de uma economia dividida entre o setor da grande lavoura e o da subsistência, como afirma Prado Júnior ${ }^{36}$, é onde se encontra a explicação para a estrutura da sociedade brasileira, que, de um lado, é marcado pela "abastança, prosperidade e grande atividade econômica; doutro, pela falta de satisfação da mais elementar necessidade da grande massa da população: a fome."

A pecuária, de início praticada essencialmente no semiárido nordestino, possuiu aí tão elevada expressão que o historiador Capistrano de Abreu ${ }^{37}$ definiu-o como sendo o lugar da civilização do couro. Um trabalho baseado na mão de obra livre, mas não assalariada, pois o pagamento se dava por intermédio da "quarteação"; um sistema em que a cada quatro bezerros nascidos vivos, ao vaqueiro, se destinava um, e os demais, ao patrão. Para Darcy Ribeiro ${ }^{38}$, a pecuária no Nordeste do Brasil, em função do sistema de remuneração, exerceu forte atração sobre os homens livres do período colonial que vislumbraram a possibilidade de exercer uma atividade autônoma, e mesmo de tornarem-se proprietários de fazendas de gado. Mas o criatório não requer mão de obra em abundância, as estimativas é a de que mesmo uma fazenda de grande porte precisava, no máximo, de vinte homens, pois a criação era extensiva e restava aos cuidados de um vaqueiro, homem de confiança e representante dos interesses do proprietário, com seus auxiliares. Ressalte-se que o dono do empreendimento vivia nas áreas urbanas, entreposto comercial de carne e de couro, e aparecia na fazenda quando da contagem e da separação dos animais.

A pecuária, assim como as demais atividades subsidiárias, não rompeu com a dinâmica de uma economia voltada para fora, sem mercado consumidor interno e de apartação de grupos populacionais com elevada concentração de riqueza e de miseráveis. A pecuária não realizava o sonho dos vaqueiros, pois as condições climáticas, onde imperam períodos que se alternam em anos de "bons invernos" com anos de seca, funcionava como mecanismo de apropriação de capital em favor dos fazendeiros. Porém, a representação exclusiva do sertão miserável, da seca, contribuiu para escamotear a produção de lucro aí realizada:

As reflexões acerca da economia do semiárido, que se assentam na existência de um baixo fluxo monetário, criaram a falsa impressão de que este era um locus não gerador de lucro, o que, obviamente, não se verifica na realidade. Esta perspectiva de análise, de fato, induz a se enxergar aí tão somente a pobreza. No sertão há, desde sua ocupação, produção de lucro. Sua apropriação é que se realiza 
fora do espaço produtor. Pode-se até falar em lucro fácil, considerando que, após o investimento inicial que dá partida ao processo de produção, quase não se faz necessário adiantar novamente dinheiro na produção, por ser mínima a necessidade de reinversões e porque não há nem mesmo remuneração de trabalho. O lucro torna-se a se reproduzir sem necessidade de remuneração dos fatores de produção. Feito o investimento inicial, realiza-se a circulação do capital sem que se proceda a novos adiantamentos ${ }^{39}$.

Em suma, tem-se que no período colonial de dependência portuguesa a dinâmica de uma economia agroexportadora, baseada em relações de trabalho escravistas e pré-capitalista, fundou os pilares de uma sociedade onde um grupo minoritário se consolidou como apropriador quase absoluto da produtividade, enquanto, de outro lado, condenou a uma reprodução social miserável uma grande massa populacional, que se manteve, até contemporaneamente, estagnada nesta condição de vida, e num nível intermediário, forjou-se um grupo de trabalhadores especializados e autônomos, que embora muito distantes, em termos materiais, dos detentores do grande capital, possuem condições de vida bem mais vantajosas em relação aos que se encontram ao rés da pirâmide.

\section{PODER E EDUCAÇÃO}

A discussão acerca da questão do poder no Brasil colonial deve considerar a existência de várias fontes e de diversos agentes. Isto porque não são tão precisos os limites que configuravam a esfera pública e a privada, e, principalmente, porque a autoridade estatal que se impunha a partir da Metrópole tinha a sua legitimidade esmaecida pelas barreiras impostas pela distância.

No concernente ao poder público, Wehling e Wehling ${ }^{40}$ apontam duas teses que se contradizem quanto a sua presença e importância na organização político-jurídica. Uma defende que a presença do Estado no Brasil antecedeu o povo. Isto porque a divisão e distribuição do espaço configuravam uma política estatal, pois não foi outro senão o poder público que definiu quem realizaria e onde ocorreria a exploração da riqueza, com base em uma parafernália de instrumentos formais, como cartas de doação, forais etc. A outra tese sustenta que o poder local se sobrepôs à autoridade do Estado, pois os mandatários regionais exerciam seu poder a partir das famílias patriarcais e latifundiárias. Exemplos abundam por todo o território brasileiro colonial. Wehling e Wehling esclarecem que o poder do Estado foi diluído e fragmentado "com o mandonismo rural dos pequenos déspotas locais, como ocorreu com sucessivas gerações da família Garcia D'Ávila, na Bahia, ou com Rafael Pinto Bandeira, no Rio Grande do Sul” ${ }^{41}$.

É certo que prevaleceu a família patriarcal na disputa pelo poder, seja encampando-o ou confrontando-o, mas em alguns locais e conjunturas sobressaiuse o Estado. Também, ainda sob o domínio português, houve por bem se estruturar uma burocracia especializada, o aparato institucional já perceptível no século XVIII, principalmente através das câmaras municipais, foi se tornando mais 
visível à medida que se adentrou o século XIX. No entendimento de Wehling e Wehling ${ }^{42}$, "parte crescente desses funcionários vai assumindo, pela exigência de maior racionalidade e eficiência administrativa, um caráter cada vez mais profissional e burocrático.”

O Brasil do século XVI ao XVIII constituía-se num país de uma maioria de iletrados, excetuando-se os membros das ordens militar, eclesiásticas e do Estado, oriundos da Metrópole ou seus descendentes diretos. Os indígenas, sob orientação dos padres, quando muito tinham acesso a conhecimentos rudimentares da língua portuguesa. Esta estrutura foi-se modificando em consonância com a transformação administrativo-política, mais fortemente com a instituição e consolidação do Império. Tem-se aí, como consagrado no pensamento do historiador e antropólogo Gilberto Freyre ${ }^{43}$, o recuo da casa grande e da senzala e o aparecimento dos sobrados e dos mucambos. A sociedade antes predominantemente rural vai paulatinamente se urbanizando. Esta mudança na paisagem do Brasil deslocou o centro de poder e, consequentemente, alterou os personagens que detinham os meios e ocupavam os espaços de dominação. A estrutura dicotômica da casa grande e senzala quebrou-se e possibilitou a emergência de uma nova nobreza: os bacharéis.

Esclarece Freyre ${ }^{44}$ que, após a Independência, recrudesce o movimento dos filhos dos senhores de engenho e das famílias de maior poder aquisitivo que vão à Coimbra, Montpelier, Paris e outras cidades europeias em busca de educação superior, normalmente incentivados por algum padre ou um parente doutor, maçom ou residente no Velho Mundo. Estes jovens formavam-se, principalmente, em Direito e Medicina. Inicia-se com o retorno dos doutores formados alhures e afeitos aos costumes e as novas concepções filosóficas e políticas um embate nas províncias brasileiras com as ideias defendidas pelos velhos mandatários locais. Com o primeiro Pedro, assistiu-se ao aparecimento no cenário nacional do bacharel, um personagem que abriu uma fissura na estrutura social dividida basicamente entre proprietários de fazendas e comerciantes, de um lado, e escravos e trabalhadores inseridos em relações pré-capitalistas, de outro lado, sem, contudo, haver alteração no comando do poder, que se mantinha absoluto nas mãos dos velhos senhores, na sua maioria iletrados. Já com o segundo Pedro, ele próprio admirador dos pensadores iluministas, os bacharéis vão adquirindo visibilidade no cenário político nacional, ocupando postos de comando na administração pública, embora o poder tenha se mantido na posse dos de sempre, principalmente nas províncias.

Apesar de no século XIX ter ocorrido um alargamento do poder público por intermédio da criação de novas organizações político-administrativas e da ocupação dos cargos criados pelos bacharéis que migraram da Metrópole, quando do deslocamento do poder central do Império português para o Brasil, e pelos jovens filhos dos brasileiros abastados que se formaram nas Universidades Europeias, além daqueles que, numa etapa posterior, se formaram em Direito, Medicina, Filosofia e Matemática, em Olinda, Salvador e Rio de Janeiro, não se observou 
alterações na dinâmica da dominação. Isto pode ser observado quando se analisa a participação política do conjunto da população brasileira, pois se verifica que se mantinha uma política feita por poucos e para seu próprio benefício.

A circulação de pensamentos filosóficos e políticos, que se opunham ao tradicionalismo monárquico, reverberou-se no Brasil com os bacharéis que entraram em contato com os ideais iluministas. É interessante notar, como observa Cury ${ }^{45}$, pelo menos no plano da proclamação, os direitos sociais no Brasil, por exemplo, delinearam uma trajetória assemelhada aquela apontada por Marshall ${ }^{46}$, para o mundo europeu, no qual os direitos civis tiveram seu advento do século XVIII, os direitos políticos no século XIX e os direitos sociais no século XX. Mas a semelhança se resume tão somente a este aspecto, pois ainda que as ideias dos ilustrados provenientes dos bacharéis fossem quase invariáveis em suas concepções originais, o mesmo não pode ser dito quanto a passagem do plano das ideias à prática cotidiana. Isto porque as relações sociais permaneceram submetidas a um tipo de autoritarismo despótico mais próximo das características do patriarcalismo feudal.

Ainda numa comparação dos direitos sociais inaugurados na Europa e no Brasil, vale destacar que Marshall ${ }^{47}$ esclarece que os direitos sociais europeus, quando do princípio de sua instituição, "compreendiam um mínimo e não faziam parte do conceito de cidadania. A finalidade comum das tentativas voluntárias e legais era diminuir o ônus da pobreza sem alterar o padrão da desigualdade”. Para o Brasil, pode-se afirmar que os esforços visando a instituição legal dos direitos sociais encontravam-se distante da possibilidade de geração de cidadania, pois não visavam a eliminação da pobreza e muito menos a diminuição da desigualdade.

A Constituição de 1824, quando refletida na perspectiva da garantia dos direitos políticos, é esclarecedora quanto às manobras jurídicas que muitas vezes ensaiam a perquirição de uma universalidade quando, na verdade, concretizam privilégios de segmentos bem determinados da sociedade. Seu texto destoava muito da realidade social escravocrata, patriarcal e colonialista, ao proclamar, em seu art. 179, "a inviolabilidade dos Direitos Civis, e Políticos dos Cidadãos Brazileiros, que tem por base a liberdade, a segurança individual, e a propriedade, é garantida pela Constituição do Império” (art. 179).

Esta Constituição, no entendimento de Boris Fausto" ${ }^{48}$, "nasceu de cima para baixo, imposta pelo rei ao povo", trouxe, entre os seus dispositivos, regras que apresentavam restrições e limites no tocante à participação política na medida que estabeleciam o sufrágio censitário. As eleições eram feitas indiretamente, em "dois graus", como se dizia na época. No primeiro grau, os votantes ("massa dos cidadãos") escolhiam os eleitores, e estes, em segundo grau, escolhiam os ocupantes dos cargos públicos. Para votar nas eleições, era preciso ter pelo menos 25 anos e possuir renda líquida anual de cem mil réis. Nas eleições de segundo grau podiam votar todos os que estavam aptos a participar nas eleições de primeiro grau, sendo necessário, todavia, ter o dobro da renda, isto é, duzentos mil réis ${ }^{49}$. Por outro lado, abria-se a participação para os 
analfabetos, que tanto podiam votar como ser votados, desde que atendessem ao requisito referente a renda.

Poder-se-ia pensar que nos encontramos diante de uma iniciativa, considerando-se a regra para o eleitor analfabeto, podendo até imaginar que se tencionava construir uma ponte que poderia futuramente funcionar como um caminho para promoção da cidadania, dado que o direito de votar e ser votado estaria assegurado, fazendo-se, então, necessário que a partir daí se envidassem esforços para solucionar o problema do analfabetismo. Entretanto, é preciso considerar que o analfabetismo predominava entre os senhores de engenho e os proprietários de grandes lavouras; enquanto os trabalhadores, além de se encontrarem nesta situação educacional, estavam inseridos em relações de trabalho não assalariadas, na condição de escravo ou de relações pré-capitalistas. Portanto, mesmo os poucos trabalhadores assalariados podiam até atender ao requisito da renda referente ao primeiro grau, de corte de cem mil reis, mas dificilmente poderiam ser votados e ocupar cargos públicos, pois o patamar de duzentos mil reis era quase inatingível na estrutura do mercado de trabalho existente à época.

Estas manobras políticas que parecem indicar uma intenção de mudança quando, na verdade, se tratam de estratégias para manter o status quo dominante, podem ser percebidas quando se traz para a discussão a mudança nas regras concernentes aos direitos políticos. De acordo com Arruda $^{50}$, no ano de 1881 se aprovou a "Lei Saraiva", já no limiar do século XX e com a redução de abastados que se mantinham iletrados, que tornou mais rigorosa a comprovação da renda e estabeleceu a proibição do voto do analfabeto. Portanto, se da vigência das regras anteriores até esta data se verificou a participação efetiva na política de algum indivíduo estranho às elites, agora esta era uma possibilidade absolutamente vetada. Com o advento da República, abandonou-se esta estratégia tão visível de obstrução à participação popular na política para se retomar a fórmula anterior, onde o direito se trata de uma virtualidade sem nenhuma possibilidade de concretizar-se na realidade. A primeira Constituição republicana, promulgada em 1891, aboliu os critérios econômicos como mecanismos restritivos, mas manteve o impedimento do voto do analfabeto, o que praticamente deixou inalterado o número de eleitores, pois se verificou que somente $2,2 \%$ da população passou a participar das eleições. No art. 70 da nossa primeira constituição republicana, a Constituição de 1891, constava textualmente o seguinte:

Art. 70. São eleitores os cidadãos maiores de 21 anos que se alistarem na fórma da lei:

$\S 1^{\circ}$ Não podem alistar-se eleitores para as eleições federaes ou para as dos Estados:

1. Os mendigos;

2० Os analphabetos;

3०As praças de pret, exceptuados os alumnos das escolas militares de ensino superior; 
4 Os religiosos de ordens monásticas, companhias, congregações, ou comunidades de qualquer denominação, sujeitas a voto de obediência, regra, ou estatuto, que importe a renúncia da liberdade individual.

§ 2० São inelegíveis os cidadãos não alistáveis.

Quanto ao tratamento da educação na Constituição de 1824, é interessante salientar, primeiramente, alguns pontos referentes a formação e aos debates da Assembleia Nacional e Geral Constituinte, de 1823, pois o olhar sobre as propostas de projetos apresentadas e os debates que se seguiram, definidores de suas hierarquizações e de suas vigências, mesmo detendo-se exclusivamente naqueles direcionados para a educação, permite a percepção de como a cultura configurou e se refletiu no ordenamento jurídico nacional. Esta é uma questão que remonta ao perfil dos parlamentares que formaram a Constituinte, uma vez que aí já se encontram presentes os elementos que dão substância ao descompasso entre as ideias elaboradas, defendidas e concretizadas na forma de leis e a realidade na qual supostamente estão alicerçadas e para a qual se destinam, o velho e sempre atual descompasso entre o texto constitucional e os fatores reais de poder.

A Assembleia Constituinte é uma decorrência da crise política derivada das insatisfações com o domínio português, que adquiriu contornos mais dramáticos com a conjuração mineira. Em última instância, trata-se de uma manobra que procura estender o domínio daqueles mais ligados à Metrópole sobre a elite nativa, insatisfeita com o peso da carga tributária e com as dificuldades interpostas à acumulação de capital mais substancial. O sentimento nacionalista ora recrudescente está assentado no desejo de implantação de uma administração dos recursos do país recém independente destituído da influência lusitana. E o caminho vislumbrado para este intento passava pela reorganização jurídico-política, que possibilitaria o funcionamento de um legislativo capaz de assegurar os interesses da elite nativa, não mais satisfeita com a intermediação que Portugal fazia entre os produtores locais e o mercado europeu. Vê-se que já estão presentes na Constituinte de 1823 as forças geradoras da desorganização da dependência portuguesa e, por conseguinte, da organização da dependência inglesa neocolonial.

Duas frentes se destacam nesta Constituinte: a corrente nacionalista, insegura, contraditória e confusa quanto aos seus objetivos, abrigada no partido liberal; e a corrente tradicionalista, agregada no partido português, que tencionava a manutenção do status quo. Na verdade, uma oposição de interesses pelo alto, uma fissura na estrutura de poder sem a participação popular. A composição da Constituinte demonstra esta característica, como esclarece Chizzotti ${ }^{51}$, foi formada por uma elite que contava com a participação de uma "ampla maioria de bacharéis em direito com cargos públicos, 16 clérigos, 2 matemáticos e 2 médicos.”

O tema da educação aparece já no discurso inaugural da Constituinte, quando D. Pedro I ressalta a necessidade de uma regulação específica que possibilitasse a extensão das ações já realizadas. Chizzotti ${ }^{52}$ extrai dos ANNAES DO PARLAMENTO BRASIELEIRO a seguinte fala do Imperador: "tenho promovido os estudos públi- 
cos, quanto é possível, porém, necessita-se de uma legislação especial.” Os esforços empreendidos se referem ao Colégio das Educandas, direcionados às moças "bem nascidas", filhas das famílias abastadas, instruídas nesta instituição que funcionava sob a direção do bispo do Rio de Janeiro; e a Escola de Ensino Mútuo que, como explica Chizzotti ${ }^{53}$, é um modelo de ensino inspirado na experiência inglesa de instrução geral visando a formação da mão de obra de qualificação mais aprimorada requisitada pelo capitalismo industrial. No Brasil, esta experiência se deu a partir da formação de soldados encaminhados pelas Províncias, que se formavam e passavam, posteriormente, a exercer o ofício de professor em seus locais de origem. Uma iniciativa fadada ao fracasso, enquanto possibilidade de instrução pública da população em geral, uma vez que não havia interesse dos presidentes provinciais na alteração da dinâmica da economia que se assentava na empresa agroexportadora, demandante de uma quantidade reduzida de mão de obra qualificada, portanto, não seriam alocados recursos para uma educação massificada, o que se daria no máximo para o funcionamento de uma escola que formasse alguns poucos afortunados que ocupariam as funções burocráticas dos negócios rurais e urbanos.

$\mathrm{Na}$ Comissão de Instrução, duas propostas monopolizaram os debates na Constituinte de 1823: a promoção da educação da mocidade e a criação de universidades. De acordo com Chizzotti ${ }^{54}$, a primeira foi assaz discutida, principalmente no quesito referente à criação de um concurso para motivar a elaboração de um plano geral de diretrizes do sistema educacional a ser implantado. Em suma, um tratado de educação física, moral e intelectual para a mocidade brasileira, como previsto em decreto que objetivava dar organicidade aos trabalhos da Comissão. Contudo, as discussões giraram em torno de questiúnculas, como o valor que deveria ser pago ao vencedor do concurso, que comenda ou medalha deveria ser conferida, se deveria haver agradecimento à nação no caso de o vencedor ser estrangeiro. Discussões estas que atravessaram meses sem que se discutisse o essencial, de tal maneira que este tema foi esvaziado e tendo-se sobressaído o dispositivo legal que garantia a ampliação da educação privada, ou seja, um instrumento que permitia a todo cidadão abrir escola elementar, sem os trâmites legais de autorização prévia e sem licença e exames requerentes.

Já a proposta de criação das universidades brasileiras foi encaminhada de forma mais objetiva e chegou mesmo a atropelar a proposta direcionada para a instrução pública elementar. De tal maneira que, sob pressão de estudantes brasileiros em Coimbra, logo a ideia tomou corpo e foi remetida sob regime de urgência para a Comissão de Instrução. Em seguida, a Comissão apresentou à Constituinte o Projeto de Lei, em que consta, dentre outras, as seguintes propostas de ordenações:

1. Haverão duas universidades, uma na cidade de São Paulo e outra na de Olinda; nas quais se ensinarão todas as ciências e belas letras.

3० Em tempo competente se designarão os fundos precisos a ambos os estabelecimentos.

4 Entretanto haverá desde já um curso jurídico na cidade de São 
Paulo para o qual o governo convocará mestre idôneos, os quaes se governarão provisoriamente pelos estatutos da universidade de Coimbra, com aquellas alterações e mudanças que eles, em mesa presidida pelo Vice-Reitor, julgarem adequadas às circunstâncias e luses do século. (ANNAES DO PARLAMENTO BRASILEIRO, Assembléia Constituinte. Sessão de 19 de agosto de 1823, I, t. 4º, p. 105).

Chizzotti ${ }^{55}$, em sua crítica à Constituinte, salienta que os debates que se seguiram à apresentação deste Projeto de Lei, em discursos tão exagerados quanto inócuos, concentraram-se em questões bairristas pela disputa para sediar as universidades, onde cada representante procurava ressaltar as qualidades de sua província e atacava as outras que se apresentavam como proponentes. Discutia-se, então, desde os sotaques regionais à vida mundana das províncias, que podiam influir negativamente ou positivamente na formação dos acadêmicos. Por outro lado, a origem e volume dos recursos necessários à criação e à manutenção foram questões que passaram ao largo das discussões. Enfim, após três meses, sobrepôs-se a ideia da criação do curso jurídico na cidade de São Paulo, tal como proposto no Projeto de Lei.

Como resultado dos trabalhos da Comissão de Instrução, tem-se que a educação da mocidade brasileira, como argumenta Chizzotti ${ }^{56}$, "ficou absolutamente relegada à iniciativa privada até o Ato Adicional de 1834 e a criação da universidade foi mais um motivo de emulação entre deputados provinciais, que proposta efetiva para a criação de estudos superiores." Ressalte-se que o imperador, diante da percepção de que ocorrera um avanço de oposicionistas e tencionando agradar os liberais sediados em Portugal, dissolveu a Constituinte, deportou deputados e conteve à força movimentos políticos de insatisfeitos em algumas Províncias. Por fim, nomeou uma comissão que tinha o objetivo de redigir uma Constituição, mas sob sua orientação direta. $\bigcirc$ texto constitucional foi enviado ao Senado da Câmara e, em seguida, aos 25 de março de 1824, foi outorgada pelo Imperador, onde no que se refere à educação observam-se as seguintes ordenações, que se localizam no título 8 $^{\circ}$, Das Disposições Geraes e Garantias dos Direitos Civis e Políticos dos Cidadãos Brazileiros, no Art. 179, onde se lê respectivamente nos parágrafos XXXII e XXXIII: "A instrução primaria, e gratuita a todos os Cidadãos" e "Collegios e Universidades, aonde serão ensinados os elementos das Sciencias Bellas Letras, e Artes." ${ }^{77}$

Darcy Ribeiro ${ }^{58}$, em discurso tão irônico quanto perspicaz, quando de sua palestra no Simpósio sobre Ensino Público, na 29o Reunião da Sociedade Brasileira para o Progresso da Ciência, realizada em julho de 1977, talvez tenha produzido a crítica que deixa mais claro os interesses que estão na base das ações direcionadas para a elaboração de um sistema educacional no período aqui enfocado. Afirma o autor, em sua fala, que não se encontra no povo, mestiço, tropical, herdeiros lusitanos de um catolicismo barroco, as causas determinantes de nosso atraso, mas na melhor parte de nosso povo, ou seja, nas características de nossa classe dominante. Isto porque se gerou aqui uma economia capaz de 
proporcionar altos lucros, mas que nas relações de produção e de trabalho aqui forjadas elaboraram-se estruturas que mantêm o povo brasileiro constrangido, atrasado e deformado.

A eficácia da classe dominante brasileira, na construção de estruturas sociais capazes de tal feito, se mostra plenamente no sistema educacional. Darcy Ribeiro, ainda neste discurso de 1977, indica a ação de D. Pedro II que, enquanto a Argentina, o Chile e o Uruguai, estendiam a educação básica para todos, criava o Instituto de Surdos e Mudos e o Instituto Imperial dos Cegos, como exemplo da intencionalidade na criação e manutenção de uma estrutura educacional inapta, mas que aparece aos incautos como incapacidade. O antropólogo é peremptório ao afirmar que não houve fracasso no esforço de universalizar o ensino no Brasil, dado que se almejava justamente fazer o que de fato fora realizado, pois ao se manter a maioria imersa na ignorância garante-se a hegemonia de classe. "Perpetua-se, em consequência, a sábia tutela que a elite educada, ilustrada, elegante, bonita, exerce paternalmente sobre as massas ignaras." ${ }^{59}$

\section{CONCLUSÃO}

Atendo-se tão-somente a normatização direcionada à educação que foi produzida no período colonial, poder-se-ia deduzir que desde tempos remotos existe no Brasil um aparato legal capaz de garantir a instrução de sua população. Entretanto, quando se traz à tona o sistema de produção, as relações de trabalho e a estrutura social e se faz uma confrontação com tais instrumentos legais, verifica-se que há uma enorme distância entre o que foi idealizado e concretizado na forma jurídica e as condições reais da vida cotidiana para a qual a forma jurídica está direcionada. Numa linguagem mais constitucionalista, poderíamos afirmar que há uma tensão entre a "vontade de Constituição" e os "fatores reais de poder".

A garantia do ensino primário gratuito a todos os cidadãos normalizado no ordenamento brasileiro, à primeira vista, aparece como um mecanismo que corrobora com a efetivação do ideal iluminista de igualdade, uma vez que se estaria dotando os indivíduos da capacidade de competição para alcançar os meios garantidores de uma sobrevivência em condições mínimas de disputa com os outros membros da sociedade. Porém, tal pressuposto é absolutamente negado pelas relações de trabalho que mantêm a maioria dos indivíduos inseridos em relações pré-capitalistas, seja na condição de escravo ou do trabalho em troca de víveres e moradia. Portanto, o sentido da expressão "gratuito a todos os cidadãos" deve ser compreendido como sendo referente à parcela da população que é proprietária ou descendente de proprietários de grandes extensões de terras, plantadores e donos de engenhos ou de empreendimentos comerciais, pois os demais membros da sociedade encontravam-se, em função de suas condições de sobrevivência, impossibilitados de por iniciativa própria buscar se instruir.

Deste modo, está-se prevendo a utilização dos recursos do Estado como um mecanismo de manutenção e mesmo de aprofundamento da distância social, 
assim invertendo a ideia de universalização do direito à educação. Isto fica ainda mais perceptível, quando se traz à luz a norma que prevê a criação do ensino superior. Ora, se nem mesmo ao ensino básico a massa da população poderia ascender, o que dizer então da possibilidade de ingressar no ensino superior. Desta possibilidade, ficam de fora também grande parte dos trabalhadores assalariados e de pequenos proprietários e seus descendentes, estes últimos por questões de lógica de sobrevivência, da necessidade de passarem à condição de força de trabalho, que é o que acontece nas economias onde prevalecem pequenos grupos que se apropriam largamente da produtividade, assim impedindo que os pequenos tenham ganhos relevantes.

Por outro lado, poder-se-ia considerar que a ordenação jurídica imperial direcionada à educação visava uma passagem da economia baseada na empresa agroexportadora para a empresa industrial. Mas, a este argumento pode se objetar, como se buscou demonstrar ao longo do texto, que as forças detentoras do domínio econômico e político, seja por inviabilidade ocasionada pela dependência econômica do centro ou por interesse em manter a estrutura econômica vigente, que possibilitava lucros extraordinários, não desejavam migrar o capital do setor primário da economia para o secundário.

É importante que se perceba, como afirma Apple a partir de uma teoria crítica da educação, que

A educação é um local de luta e conciliação. Ela também serve como substituto para batalhas maiores com relação àquilo que as nossas instituições deveriam fazer, a quem elas deveriam servir, a quem deveria tomar essas decisões. E ainda assim, por si só, ela é uma das mais importantes arenas por meio da qual são trabalhados recursos, forças e ideologias específicas para políticas, finanças, currículo, pedagogia e avaliação na educação. Assim, a educação é tanto causa como efeito, determinante e determinada, Por causa disso, nenhum ensaio pode apresentar uma imagem completa da complexidade ${ }^{60}$.

Enfim, não é exagero afirmar que, a partir do momento em que emergiu na sociedade brasileira a crença de que a modernização industrial e o conhecimento científico como tal seriam basilares para se retirar o país do atraso socioeconômico e cultural (um consenso que foi se estabelecendo a partir do segundo quartel do século XX para se consolidar na primeira metade deste mesmo século), esta crença acabou por deparar-se com impedimentos de valor moral já incrustados na sociedade, representados inclusive pela ordenação jurídica até então produzida, de caráter nitidamente excludente, o que promoveu impasse que se constituiu como um dos principais obstáculos à universalização da educação como política pública a ser desenvolvida pelo Estado brasileiro. 


\section{REFERÊNCIAS}

ABREU, João Capistrano de. Caminhos antigos e povoamento do Brasil. Fortaleza: Universidade Federal do Ceará (UFC), 1999.

APPLE, Michael. Entre o Neoliberalismo e o Neoconservadorismo: educação e conservadorismo em um contexto global. In: BURBULES, Nicholas C. e TORRES, Carlos Alberto (orgs.). Globalização e Educação. Trad. Ronaldo Cataldo Costa. Porto Alegre: Artmed Editora, 2004.

ARRUDA, Gerardo Clésio Maia. Trabalho, riqueza e dominação no Sertão do Nordeste do Brasil. Salvador: Revista CEAS, n. 219, set-out/2005. p. 43 - 62.

ARRUDA, Gerardo Clésio Maia et all. Direitos humanos à luz dos processos culturais históricos: uma reflexão a partir da constitucionalização dos direitos políticos brasileiros. In: CAÚLA, Bleine Queiroz et al. Diálogo ambiental, constitucional e internacional. Rio de Janeiro: Lumens Juris, 2015.

BOSI, Alfredo. Dialética da colonização. São Paulo: Companhia das Letras, 1992.

BRASIL. Annaes do Parlamento Brasileiro, Assembleia Constituinte. Sessão de 19 de agosto de 1823. Disponível em: <http://www.senado.leg.br/publicacoes/anais/pdf/ACE/ATAS2-segundo_Conselho_de_Estado_1822-1834.pdf>. Acesso: 22 Fev. 2015.

. Constituição de 1824. 1824 / Octaciano Nogueira. 3a ed. Brasília: Senado Federal, Subsecretaria de Edições Técnicas, 2012.

Constituição de 1891. 1891/Aliomar Baleeiro. 3a ed. Brasília: Senado Federal, Subsecretaria de Edições Técnicas, 2012.

Instituto Brasileiro de Geografia e Estatística (IBGE). Censo Demográfico 1940. Disponível em: http://censo1940.ibge.gov.br/>. Acesso em: 05 fev. 2015.

.Instituto Brasileiro de Geografia e Estatística (IBGE). Censo Demográfico 2000. Disponível em: http://censo1940.ibge.gov.br/>. Acesso em: 05 fev. 2015.

.Instituto Brasileiro de Geografia e Estatística (IBGE). Censo Demográfico 2010. Disponível em: http://censo1940.ibge.gov.br/>. Acesso em: 05 fev. 2015.

BURBULES, Nicholas C. e TORRES, Carlos Alberto (orgs.). Globalização e Educação. Trad. Ronaldo Cataldo Costa. Porto Alegre: Artmed Editora, 2004, p. 12.

CHIZZOTTI, Antônio. A Constituinte de 1823 e a educação. In: FAVERO, Osmar (Org.). A educação nas constituintes brasileiras 1823 -1988. Campinas: Editora Autores Associados, 1996. 
COUTO, Jorge. A construção do Brasil: ameríndios, portugueses e africanos, do início do povoamento a finais de quinhentos. Lisboa: Editora Cosmos, 1998.

CURY, Carlos Roberto Jamil et al. A relação educação-sociedade-Estado pela mediação jurídico-constitucional. In: FAVERO, Osmar (Org.). A educação nas constituintes brasileiras 1823 -1988. Campinas: Editora Autores Associados, 1996.

DAMATTA, Roberto, Relativizando: uma introdução à Antropologia Social. Rio de Janeiro: Rocco, 2010.

DOWBOR, Ladislau. A formação do capitalismo dependente no Brasil. São Paulo: Brasiliense, 1982.

FAUSTO, Boris. História do Brasil. São Paulo: EDUSP, 2008.

FERNANDES, Florestan. A sociologia numa era de revolução social. Rio de Janeiro: Zahar Editores, 1976.

FREYRE, Gilberto. Casa Grande \& Senzala. Rio de Janeiro: Global Editora, 2013.

FREYRE, Gilberto. Sobrados e Mucambos. Rio de Janeiro: Editora Record, 1998.

FURTADO, Celso. O longo amanhecer: reflexões sobre a formação do Brasil. Rio de Janeiro: Paz e Terra, 1999.

HOLANDA, Sérgio Buarque de. Visão do paraíso: os motivos edênicos no descobrimento e colonização do Brasil. São Paulo: Brasiliense, 1994.

MANACORDA, Mario Alighiero. História da Educação: da antiguidade aos nossos dias. Trad. Gaetano Lo Monaco. 13. ed. São Paulo: Cortez, 2010.

MARSHALL, T. H. Cidadania, classe social e status. Rio de Janeiro: Zahar Editores, 1967.

MICELI, Paulo. O feudalismo. São Paulo: Editora da UNICAMP, 1986.

PNUD. Programa das Nações Unidas para o Desenvolvimento. Relatório de Desenvolvimento Humano 2013. Disponível em: http://www.pnud.org.br/ arquivos/rdh-2013.pdf. Acesso em 05 maio 2015.

PRADO JÚNIOR, Caio. História econômica do Brasil. São Paulo: Brasiliense, 1985.

RIBEIRO, Darcy. O povo brasileiro: a formação e o sentido do Brasil. São Paulo: Companhia das Letras, 1999.

RIBEIRO, Darcy. Sobre o óbvio. In: <http://www.cefetsp.br/edu/eso/filosofia/ sobreobviocsc.html . Acesso em: 21/02/15.

SAVIANI, Dermeval. História das Ideias Pedagógicas no Brasil. 3. ed. revista. Campinas, SP: Autores Associados, 2010. 
SCHWARZ, Roberto. Cultura e política. São Paulo: Paz e Terra, 2009.

SENNA, José Júlio. Os parceiros do rei: herança cultural e desenvolvimento econômico no Brasil. Rio de Janeiro: Topbooks, 1995.

WEHLING, Arno e WEHLING, Maria José C. de. Formação do Brasil Colonial. Rio de Janeiro: Nova Fronteira, 1994.

1 FERNANDES, Florestan. A sociologia numa era de revolução social. Rio de Janeiro: Zahar Editores, 1976, p. 314.

2 Dados extraídos dos Censos Demográficos de 1940, 2000 e 2010. Disponíveis em <http://www.ibge.gov. br> Acesso em 23/11/2015.

3 PNUD. Programa das Nações Unidas para o Desenvolvimento. Disponível em <http://www.pnud.org. br/> Acesso em 24/11/2013.

4 BURBULES, Nicholas C. e TORRES, Carlos Alberto (orgs.). Globalização e Educação. Trad. Ronaldo Cataldo Costa. Porto Alegre: Artmed Editora, 2004, p. 12.

5 Cf. BOSI, Alfredo. Dialética da colonização. São Paulo: Companhia das Letras, 1992.

6 BOSI, Alfredo. Dialética da colonização. São Paulo: Companhia das Letras, 1992, p. 11.

7 Cf. BOSI, Alfredo. Dialética da colonização. São Paulo: Companhia das Letras, 1992.

8 Cf. BOSI, Alfredo. Dialética da colonização. São Paulo: Companhia das Letras, 1992.

9 BOSI, Alfredo. Dialética da colonização. São Paulo: Companhia das Letras, 1992, p. 12.

10 MICELI, Paulo. O feudalismo. São Paulo: Editora da UNICAMP, 1986, p. 33.

11 BOSI, Alfredo. Dialética da colonização. São Paulo: Companhia das Letras, 1992, p. 13.

12 BOSI, Alfredo. Dialética da colonização. São Paulo: Companhia das Letras, 1992, p. 16.

13 Cf. HOLANDA, Sérgio Buarque de. Visão do paraíso: os motivos edênicos no descobrimento e colonização do Brasil. São Paulo: Brasiliense, 1994.

14 Cf. HOLANDA, Sérgio Buarque de. Visão do paraíso: os motivos edênicos no descobrimento e colonização do Brasil. São Paulo: Brasiliense, 1994.

15 Cf. HOLANDA, Sérgio Buarque de. Visão do paraíso: os motivos edênicos no descobrimento e colonização do Brasil. São Paulo: Brasiliense, 1994.

16 Cf. HOLANDA, Sérgio Buarque de. Visão do paraíso: os motivos edênicos no descobrimento e colonização do Brasil. São Paulo: Brasiliense, 1994.

17 SENNA, José Júlio. Os parceiros do rei: herança cultural e desenvolvimento econômico no Brasil. Rio de Janeiro: Topbooks, 1995, p. 23-24.

18 Cf. SENNA, José Júlio. Os parceiros do rei: herança cultural e desenvolvimento econômico no Brasil. Rio de Janeiro: Topbooks, 1995.

19 MANACORDA, Mario Alighiero. História da Educação: da antiguidade aos nossos dias. Trad. Gaetano Lo Monaco. 13. Ed. São Paulo: Cortez, 2010, p. 238.

20 DAMATTA, Roberto, Relativizando: uma introdução à Antropologia Social. Rio de Janeiro: Rocco, 2012, p. 101.

21 BRASIL. Constituição de 1824. 1824 / Octaciano Nogueira. 3a edição. Brasília: Senado Federal, Subsecretaria de Edições Técnicas, 2012, p. 65.

22 Cf. SCHWARZ, Roberto. Cultura e política. São Paulo: Paz e Terra, 2009.

23 SCHWARZ, Roberto. Cultura e política. São Paulo: Paz e Terra, 2009, p. 66.

24 FURTADO, Celso. O longo amanhecer: reflexões sobre a formação do Brasil. Rio de Janeiro: Paz e Terra, 1999 , p. 58.

25 FURTADO, Celso. O longo amanhecer: reflexões sobre a formação do Brasil. Rio de Janeiro: Paz e Terra, 1999, p. 61.

26 SAVIANI, Dermeval. História das Ideias Pedagógicas no Brasil. 3a edição revista. Campinas, SP: Autores Associados, 2010, p. 31.

27 Cf. DOWBOR, Ladislau. A formação do capitalismo dependente no Brasil. São Paulo: Editora Brasiliense, 1982.

28 DOWBOR, Ladislau. A formação do capitalismo dependente no Brasil. São Paulo: Editora Brasiliense, 1982, p. 31. 
29 Cf. DOWBOR, Ladislau. A formação do capitalismo dependente no Brasil. São Paulo: Editora Brasiliense, 1982.

30 Cf. DOWBOR, Ladislau. A formação do capitalismo dependente no Brasil. São Paulo: Editora Brasiliense, 1982.

31 Cf. FREYRE, Gilberto. Casa Grande \& Senzala. Rio de Janeiro: Global Editora, 2013.

32 Cf. COUTO, Jorge. A construção do Brasil: ameríndios, portugueses e africanos, do início do povoamento a finais de quinhentos. Lisboa: Editora Cosmos, 1998.

33 COUTO, Jorge. A construção do Brasil: ameríndios, portugueses e africanos, do início do povoamento a finais de quinhentos. Lisboa: Editora Cosmos, 1998, p. 285.

34 COUTO, Jorge. A construção do Brasil: ameríndios, portugueses e africanos, do início do povoamento a finais de quinhentos. Lisboa: Editora Cosmos, 1998, p. 292.

35 Cf. PRADO JÚNIOR, Caio. História econômica do Brasil. São Paulo: Editora Brasiliense, 1985.

36 PRADO JÚNIOR, Caio. História econômica do Brasil. São Paulo: Editora Brasiliense, 1985, p. 44.

37 Cf. ABREU, João Capistrano de. Caminhos antigos e povoamento do Brasil. Fortaleza: Universidade Federal do Ceará (UFC), 1999.

38 Cf. RIBEIRO, Darcy. O povo brasileiro: a formação e o sentido do Brasil. São Paulo: Companhia das Letras, 1999.

39 ARRUDA, Gerardo Clésio Maia. Trabalho, riqueza e dominação no Sertão do Nordeste do Brasil. Salvador: Revista CEAS, No. 219, set-out/2005, p. 58.

40 Cf. WeHling, Arno e WEHLING, Maria José C. de. Formação do Brasil Colonial. Rio de Janeiro: Nova Fronteira, 1994.

41 WeHling, Arno e WEHLING, Maria José C. de. Formação do Brasil Colonial. Rio de Janeiro: Nova Fronteira, 1994, p. 299.

42 WEHLING, Arno e WEHLING, Maria José C. de. Formação do Brasil Colonial. Rio de Janeiro: Nova Fronteira, 1994, p. 300.

43 Cf. FREYRE, Gilberto. Sobrados e Mucambos. Rio de Janeiro: Editora Record, 1998.

44 Cf. FREYRE, Gilberto. Sobrados e Mucambos. Rio de Janeiro: Editora Record, 1998.

45 Cf. CURY, Carlos Roberto Jamil et al. A relação educação-sociedade-Estado pela mediação jurídico-constitucional. In: FAVERO, Osmar (Org.). A educação nas constituintes brasileiras 1823 -1988. Campinas: Editora Autores Associados, 1996.

46 Cf. MARSHALL, T. H. Cidadania, classe social e status. Rio de Janeiro: Zahar Editores, 1967.

47 MARSHALL, T. H. Cidadania, classe social e status. Rio de Janeiro: Zahar Editores, 1967, p. 88.

48 FAUSTO, Boris. História do Brasil. São Paulo: EDUSP, 2008, p. 149.

49 ARRUDA, Gerardo Clésio Maia et al. Direitos humanos à luz dos processos culturais históricos: uma reflexão a partir da constitucionalização dos direitos políticos brasileiros. In: CAÚLA, Bleine Queiroz et al. Diálogo ambiental, constitucional e internacional, Rio de Janeiro: Lumens Juris, 2015.

50 ARRUDA, Gerardo Clésio Maia et al. Direitos humanos à luz dos processos culturais históricos: uma reflexão a partir da constitucionalização dos direitos políticos brasileiros. In: CAÚLA, Bleine Queiroz et al. Diálogo ambiental, constitucional e internacional, 2015.

51 CHIZZOTTI, Antônio. A Constituinte de 1823 e a educação. In: FAVERO, Osmar (Org.). A educação nas constituintes brasileiras 1823 -1988. Campinas: Editora Autores Associados, 1996, p. 33.

52 CHIZZOTTI, Antônio. A Constituinte de 1823 e a educação. In: FAVERO, Osmar (Org.). A educação nas constituintes brasileiras 1823 -1988. Campinas: Editora Autores Associados, 1996, p. 36.

53 Cf. CHIZZOTTI, Antônio. A Constituinte de 1823 e a educação. In: FAVERO, Osmar (Org.). A educação nas constituintes brasileiras 1823 -1988. Campinas: Editora Autores Associados, 1996.

54 Cf. CHIZZOTTI, Antônio. A Constituinte de 1823 e a educação. In: FAVERO, Osmar (Org.). A educação nas constituintes brasileiras 1823 -1988. Campinas: Editora Autores Associados, 1996.

55 Cf. CHIZZOTTI, Antônio. A Constituinte de 1823 e a educação. In: FAVERO, Osmar (Org.). A educação nas constituintes brasileiras 1823 -1988. Campinas: Editora Autores Associados, 1996.

56 CHIZZOTTI, Antônio. A Constituinte de 1823 e a educação. In: FAVERO, Osmar (Org.). A educação nas constituintes brasileiras 1823 -1988. Campinas: Editora Autores Associados, 1996, p. 50.

57 BRASIL. Constituição de 1824. 1824 / Octaciano Nogueira. 3.ed. Brasília: Senado Federal, Subsecretaria de Edições Técnicas, 2012, p. 87.

58 RIBEIRO, Darcy. Sobre o óbvio. In: 〈http://www.cefetsp.br/edu/eso/filosofia/sobreobviocsc.html>. Acesso em: 21/02/15. 
59 RIBEIRO, Darcy. Sobre o óbvio. In: 〈http://www.cefetsp.br/edu/eso/filosofia/sobreobviocsc.html〉. Acesso em: 21/02/15, p. 1.

60 APPLE, Michael. Entre o Neoliberalismo e o Neoconservadorismo: educação e conservadorismo em um contexto global. In: BURBULES, Nicholas C. e TORRES, Carlos Alberto (orgs.). Globalização e Educação. Trad. Ronaldo Cataldo Costa. Porto Alegre: Artmed Editora, 2004, p. 45.

FORGOTTEN PAIDEIA: CONSTRAINING ROOTS OF UNIVERSALISATION OF RIGHT TO EDUCATION IN BRAZIL

\begin{abstract}
This article resulted from an effort to point out the original causes of the hindrances developed along history, which still obstruct the universalization of the rights to education within Brazilian society. Thereby, the analysis led to the time when Brazil was a colony and later an empire, with the objective of learning about the sense of colonization, the intricacies of domination and hierarchical structures then built, and afterwards cemented. The consequences of the particular circumstances found on the craft of the dynamics of social and power relations were analyzed. Thus, the economy of the period was studied to disclose the elements that define the interest of dominant classes, understood as the cornerstones of political organization, which is the pillar of social relations. The relations of production were also examined, with the aim to check the needs on labor force, assumed as essential for the description of the evolution on rules and public policies concerning education. The conclusion is that the Constitution of 1824 is the beginning of the establishment of a legal frame on the right to education which inaugurates the wide gap between the constitutional guaranties and the sociopolitical reality of the national environment.
\end{abstract}

Keywords: Right to Education. Universalization. Constitution of 1824. Public Policies.

Submetido: 28 dez. 2015

Artigo convidado 